\title{
MORPHOLOGICAL FINDINGS IN LUNGS OF THE HORSES WITH CHRONIC OBSTRUCTIVE
} PULMONARY DISEASE (COPD)

\author{
MARINKOVIĆ D*, ALEKSIĆ-KOVAČEVIĆ SANJA* and PLAMENAC P** \\ *Faculty of Veterinary Medicine, Belgrade \\ **Institut for mother and childrens health "Dr Vukan Čupić", Belgrade
}

(Received 12. November 2006)

The frequency and characteristics of chronic obstructive pulmonary disease (COPD) based on morphological and cytological changes in equine lungs were studied in this paper. Lungs obtained from 51 horses of different age and sex were examined grossly and tissue samples were collected for pathohistological examination. Cytological examination was done on impression smears from the tracheal bifurcation. Pathohistological preparations were stained with hematoxylin eosin (HE), toluidine blue (TB), Giemsa staining, PAS staining and Pearls reaction for iron detection. The peroxidase anti-peroxidase technique was used to demonstrate CD3+ (T lymphocytes) and CD79+ (B lymphocytes). Tracheal bifurcation cytology impression smears were stained with hematoxylin eosin (HE), Giemsa staining and PAS staining.

Pulmonary emphysema and lack of pulmonary collapse were the most common gross lesions whereas alveolar emphysema was described in $70.59 \%$ of all examined horses, more frequently in the distensive form (54.90\%) and less frequently in the destructive form (15.69\%). Pathohistological chronic bronchitis/bronchiolitis, with characteristic changes in the lumen, mucosa, submucosa and smooth muscle layer was described in all examined horses. Increased immunoreactivity was described in the lungs. The most common lesions seen on cytology impression smears from the tracheal bifurcation were thick, viscous, PAS positive mucus which forms Curschmann's spirals. The dominant cell population consisted of desquamated airway epithelial cells, as well as eosinophils, neutrophils, mast cells, erythrocytes and alveolar macrophages. Primary pulmonary pathogens as well as potential contaminants and secundary infection agens were isolated bacteriologically from lung samples.

All the above-mentioned findings correlate pointing to the fact that chronic bronchitis/bronchiolitis represents the basic substrate of chronic obstructive pulmonary disease (COPD) which has a combined inflammatory and immunological etiology. Emphysema being secondary to airway obstruction.

Key words: horse, lungs, COPD, pathohistology, cytology 


\section{INTRODUCTION}

Since respiratory diseases are widely spread among the horse population and account for a substantial share of the pathology of this animal species the study of chronic obstructive pulmonary disease (COPD) in horses is of great importance. Chronic obstructive pulmonary disease belongs to the group of chronic respiratory diseases that reduce the value of sport animals and the working capacity of draught animals. The importance of this study is further illustrated by the fact that COPD is markedly similar to allergic, atopic, extrinsic asthma in humans.

Pathogenesis of the disease has not been fully elucidated, but some hypotheses have been proposed suggesting the development of the disease. With genetic predisposition, noxae (recurrent and uncured viral and bacterial infections of the airways, noxious effects of proteases and endotoxins) lead to lesions on the airway epithelium - loss of the cilia from the ciliary epithelium, desquamation of the epithelial cells of bronchioli and bronchus, as well as denudation of the basal membrane. Denudation of the basal membrane enables the antigen to establish a direct contact with the immunologically active tissues and as a result respiratory tissues become hypersensitive (McPherson and Lawson, 1974; Trailovic, 2000; Moore et al., 2004).

The pathohistological findings are very characteristic. The main pathohistological substrates of COPD include bronchitis and bronchiolitis that are characterized with extensive loss of cilia - ciliocytophtoria (Kaup et al., 1990 a,b), degeneration, necrosis and desquamation of epithelial cells. As a result of these changes in the chronic form of the disease the epithelial and goblet cells become hyperplastic and sometimes there are signs of squamous metaplasia of epithelial cells (McPherson and Thompson, 1983; Schoon and Deegen, 1983; Winder and von Fellenberg, 1987; Winder and von Fellenberg, 1988; Kaup et al., 1990 a,b; Slocombe, 2001; Robinson, 2001; Costa et al., 2001). The thickening of the muscular layer of bronchioli and bronchi (Schoon and Deegen, 1983; Winder and von Fellenberg, 1987; Winder and von Fellenberg, 1988; Costa et al., 2001; Robinson, 2001; Slocombe, 2001; Slocombe, 2003), and peribronhial and peribronchiolar infiltration of lymphocytes, macrofages, eosinophil granulocytes and plasma cells is also present (McPherson and Thompson, 1983; Winder and Fellenberg, 1987; Winder and von Fellenberg, 1988; Watson et al., 1997; Costa et al., 2001; Robinson, 2001). In the lumen of bronchi and bronchioli accumulation of a large amount of thick viscous mucus that occasionally makes mucosal plugs that may obstruct the lumen of these airways is present (McPherson and Thompson, 1983; Schoon and Deegen, 1983; Winder and von Fellenberg, 1987; Winder and von Fellenberg, 1988; Kaup et al., 1990 a,b; Costa et al., 2001; Robinson, 2001; Zinkl, 2002; Slocombe, 2003).

As a result of all the above mentioned changes obstruction of the airways occures, hindering air flow through them, particularly in the expirium leading to the consequent development of secondary emphysema and athelectasis. Thus, emphysema occurs secondarily in nature, and results from airway obstruction (McPherson and Lawson, 1974; Geisel and Sandersleben, 1987; Lopez, 2001). 
Regardless of the fact that the disease was recognized long ago, there are few data on the pathogenesis which makes the diagnosis difficult. Recently, in addition to standard diagnostic methods, cytological smears obtained by bronchoaleveolar and tracheobronchial lavage are also used. Moreover, imprints from the mucosal tissue in the tracheal bifurcation makes post-mortem diagnostic substantially easier and substantiates the diagnosis of the disease.

\section{MATERIALS AND METHODS}

The lungs were sampled from 51 horses from an abattoir; 11 young animals below 5 years of age and 40 adults aged 5-15 years; 33 male and 18 female animals, and 3 control animals with no morphological changes on the lungs. In their lifetime the animals were used for draught (50 horses) and riding (1 horse). The study comprised 216 samples of horse lungs and 54 samples of tracheobronchial lymph nodes. After macroscopic examination of the lungs and trancheobronchial lymph nodes, 5 samples were taken from each of the animals: 4 samples of the lungs (from the cranial, caudal, accessory lobe and the region close to the tracheal bifurcation that affects the lobar bronchus, respectively) for pathohistological and immunohistochemical studies, as well as one sample of the lungs for microbiological studies. From the tracheal bifurcation impressions on three glass slides were taken for cytological examinations. Samples of lungs and lymph nodes for pathohistological and immunohistochemical studies were fixed immediately after sampling for $24-48$ hours in $10 \%$ buffered formalin and after standard processing in an automated tissue processor cast in paraffin blocks. Samples of lungs for microbiological studies were placed into sterile Petri dishes immediately after sampling and transported in a portable fridge to the microbiological laboratory. Impressions of the preparations from the bifurcation of the trachea were fixed on air at $18-20^{\circ} \mathrm{C}$ for $1-2$ hours.

The paraffin sections $3-5 \mu \mathrm{m}$ thick were stained with hematoxyllin and eosin $(\mathrm{HE})$, toluidin blue (TB) Giemsa, PAS and Pearls's reaction for iron detection.

Cytological impressions - preparations from the tracheal bifurcation after air fixation were stained with hematoxyllin and eosin (HE), Giemsa and PAS.

One of the immunohistochemical methods used, was peroxidaseantiperoxidase (PAP) test with target labeling of CD3+ (T lymphocytes) CD3 (DAKO A 0452) and CD79+ (B lymphocytes) CD79 (DAKO M7051).

From the lung samples taken for microbiological studies immediately upon arrival to the microbiological laboratory direct preparations were made and stained according to Gram, Giemsa and prolonged carbol fuxine staining.

\section{RESULTS}

\section{Macroscopic findings}

Macroscopic appearance of the lungs was mainly unchanged. In 14 horses $(27.45 \%)$ the lungs had physiological shape, enlarged, pale pink, soft elastic consistency and on the section from the conductive airways viscous mucus was 
drained. In 6 horses (11.76\%) at the edges of the lungs, below the pleura, baggy enlargements were seen, filled with air, about $2 \mathrm{~cm}$ in diameter, that cracked upon touching. Lungs of 3 horses (5.88\%) were wet on section, and from the sections upon pressure a white foamy liquid was discharged, corresponding to pulmonary edema.

In 7 horses $(13,72 \%)$ at one or more lobes on the sections spontaneously or upon pressure, purulent fluid was discharged, whitish-yellow, viscous, corresponding to the diagnosis of purulent pneumonia. Focal, subpleural focal or spotty bleeding was recorded in 5 horses $(9.80 \%)$, while in one horse $(1.96 \%)$ the external and internal pleural sheets adhered with thin white threads, corresponding to the finding of focal adhesive pleuritis. In 6 horses $(11.76 \%)$ subpleurally and in pulmonary parenchyma white-yellowish nodes, $5-10 \mathrm{~mm}$, firm and characterized by concentric architecture and a calcified external and somewhat softer internal part were seen. This finding corresponds to calcified parasitic noduli. On the tracheal bifurcation in all studied horses different amounts of mucus were present.

\section{Pathohistological findings}

Changes in the bronchial and bronchiolar epithelium were manifested as loss of cilia (ciliocytophtoria) from epithelial cells as well as their degeneration, necrosis and desquamation (Fig. 1a). Proliferation of bronchial and bronchiolar epithelia was noted, thus the proliferated cells form papillomatous proliferations protruded into the lumen. Squamous metaplasia (SM) was seen in $7.84 \%$ of the studied horses (Fig. 1b). In 33 horses (64.70\%) numerous hyperplastic goblet cells filled with content were seen in the lumen of the bronchus and bronchioli. In the lumen of the airways accumulation of a large amount of thick mucus was seen. In the lumen of bronchioli or bronchus the cellular population included desquamated epithelial cells and eosinophilic granulocytes with a large number of neutrophillic granulocytes and alveolar macrophages often in the form of mucopurulent plugs (Fig. 2a).

Hyperplasia of the subepithelial bronchial glands was diagnosed in 23 horses $(45.10 \%)$. In 31 horses $(60.78 \%)$ subepithelial aggregation of lymphocytes, mastocytes, eosinophillic granulocytes, plasma cells and macrophages occasionally organized as follicles were seen. Hypertrophy of the muscular layer of bronchioliae and bronchus was evident in 13 horses $(25.49 \%)$. In 14 horses (27.45\%) in peribronchial and peribronchiolar spaces cellular infiltration consisting of: lymphocytes, macrophages, eosinophillic granulocytes and plasma cells, which may be defined as peribronchiolitis and peribronchitis was recorded. In 8 horses (15.69\%) various sizes of air filled spaces were seen, frequently with complete loss of the alveolar septa and alveoli, and a reduced number of capillaries. This finding corresponds to the presentation of destructive emphysema (Fig. 3).

In the subepithelial region of the bronchioli and bronchus a large number of lymphocytes with CD3 positive reaction and a large number of lymphocytes with CD79 reaction were seen. Except in the subepithelial region these two types of 
Acta Veterinaria (Beograd), Vol. 57, No. 2-3, 157-167, 2007.

Marinković $\mathrm{D}$ et al.: Morphological findings in lungs of

the horses with chronic obstructive pulmonary disease (COPD)

cells are seen in peribronchiolar an peribronchial tissue, and to a smaller extent in the pulmonary interstitium, alveolar septa and perivascularly.

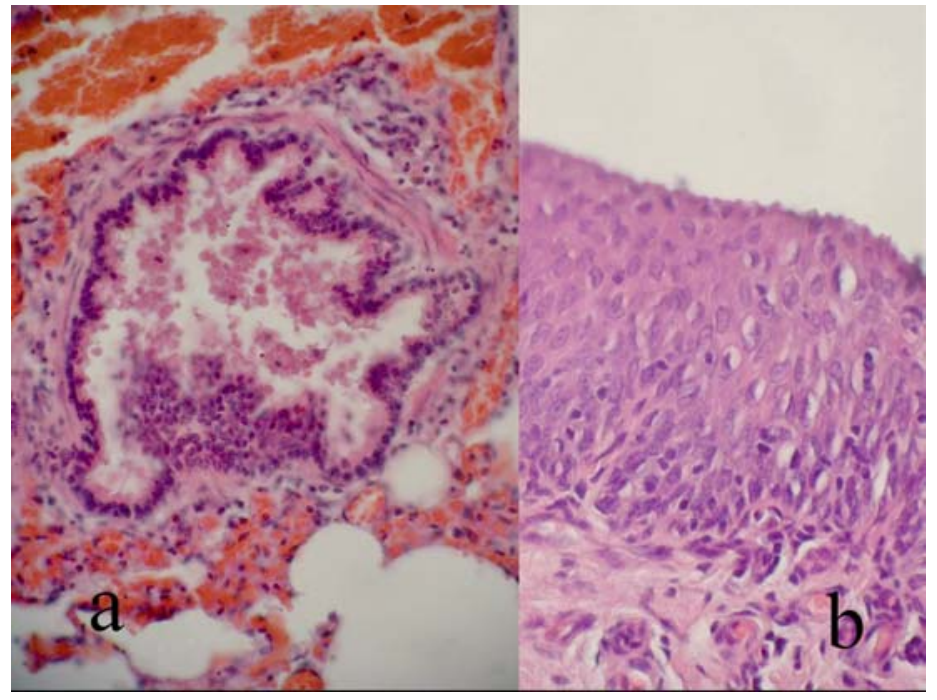

Figure 1. a. Chronic bronchiolitis with epithelial proliferation, desquamation and necrotic epithelial cells in the lumen (HE, x400); b. Squamous metaplasia of the respiratory epithelium (HE, x400)

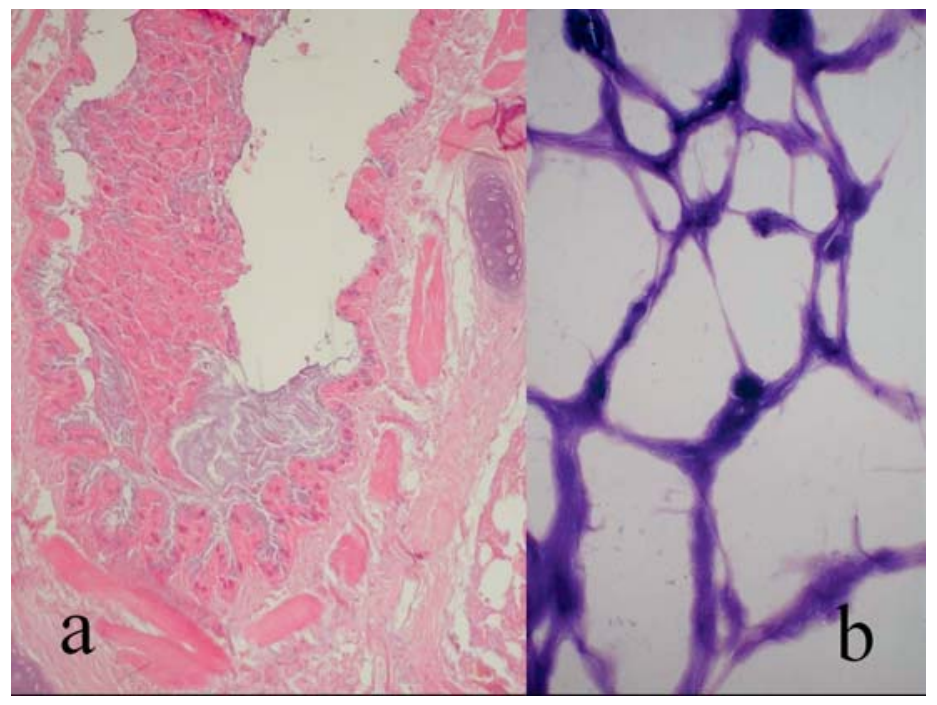

Figure 2. a. Chronic bronchitis, muco-purulent plug in the bronchial lumen (HE, x200); b. Tracheal imprint: Curschmann's spirals (Giemsa, x1000) 


\section{Cytological findings}

In cytological imprint preparations the predominant cellular population were desquamated columnar cells revealing a spectrum of degenerative changes, together with ciliocytophtoria (in 50, i.e. $98.04 \%$ of studied horses). CharcotLeyden's crystals that represent structures generated by disintegration of eosinophillic granulocytes were seen in one horse (1.96\%). Mostly nonhemolyzed erythrocytes were present in 24 horses (47.06\%). In 10 horses $(19.60 \%)$ cytological preparations revealed neutrophillic granulocytes. Alveolar macrophages, large cells with kidney-like or irregularly shaped nucleus were seen in preparations of 11 horses (21.57\%). These cells frequently contained phagocyted bacterial, epithelial cells or coal dust - coniophages. In 5 horses $(9.80 \%)$ cytological preparations revealed the presence of mastocytes. Squamous metaplasia was seen in 3 horses $(5.88 \%)$.

In addition to cytological impression preparations from the tracheal bifurcation, the presence of mucus was diagnosed in 48 horses $(94.12 \%)$. In 6 $(11.76 \%)$ horses the amount of mucus was small, disorganized while in 42 horses (82.35\%) thick viscous mucus formed Curschmann's spirals (Fig. 2b). Bacteria were found in the preparations of 25 horses $(49.02 \%)$, while Candida albicans was found in 2 horses (3.92\%).

Bacteriological findings: The following microorganisms were isolated from samples of lungs taken for microbiological examinations: Streptococcus equi (in 2 horses $-3.92 \%$ ), Streptococcus pyogenes (in 2 horses - 3.92\%), Staphylococcus aureus (in 1 horse - 1.96\%), Enterococcus sp. (in 6 horses - 11.76\%), Enterobacter sp. (in 17 horses - 33.33\%), Citrobacter sp. (in 3 horses - 5.88\%),

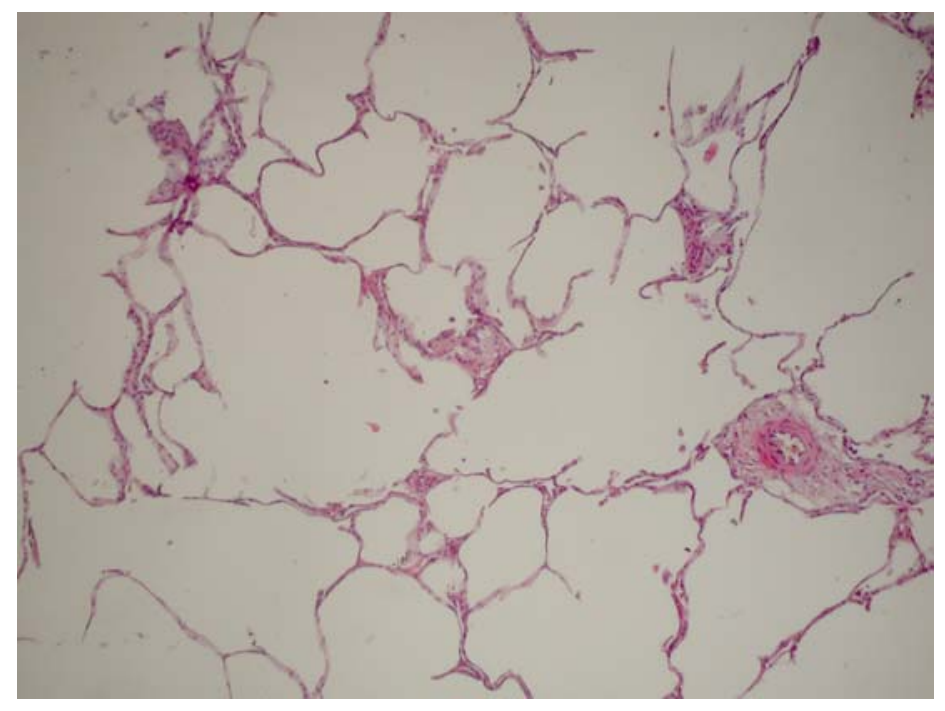

Figure 3. Destructive emphysema (HE, x100) 
Acta Veterinaria (Beograd), Vol. 57, No. 2-3, 157-167, 2007.

Klebsiella sp. (in 5 horses $-9.80 \%$ ), Proteus mirabilis (in 19 horses $-37,25 \%$ ), Pseudomonas sp. (in 28 horses - 54.90\%), Escherichia coli (in 47 horses 92.16\%), fungus Candida albicans (in 3 horses $-5.88 \%$ ).

\section{DISCUSSION}

In the material examined for this study, bronchitis/bronchiolitis of various degree was diagnosed in all studied horses, coinciding with reports of Bracher et al. (1991). Reference papers by different authors differ only slightly in the percentage of histologically verified bronchitis/bronchiolitis from $37,4 \%$ (Winder and von Fellenberg, 1987) and 38\% (McPherson et al., 1978). Conversely, in a study conducted in Switzerland chronic bronchitis/bronchiolitis of various degrees of severity was established in $62.3 \%$ to $100 \%$ of studied horses (Bracher et al., 1991). In all studied horses loss of cilia, degeneration, necrosis and desquamation of epithelial cells were found to various degrees, which is in agreement with the available reference literature (Kaup et al., 1990 a,b). Also, proliferation of bronchia/bronchiolar epithelium was recorded where these cells form papillomatous proliferations that protrude into the lumen as reported by many authors (McPherson and Thompson, 1983; Winder and von Fellenberg, 1987; Winder and von Fellenberg, 1988; Kaup et al., 1990 a,b; Slocombe, 2001). In humans during respiration or coughing these proliferates may fall off and enter the cytological material (sputum, bronchioaspirate or preparation) in the form of clusters, i.e. Creola bodies (Naylor, 1962; Naylor and Railey, 1964). Although this finding is highly suggestive of asthma it has been described in completely different circumstances, e.g. sputa of workers in steel plants or sputa of pig breeders (Plamenac et al., 1974; Đuričić et al., 2001). Due to chronic irritation squamous metaplasia (SM) developed in $7.84 \%$ of the studied horses (Schoon and Deegen, 1983; Winder and von Fellenberg, 1988; Robinson, 2001; Slocombe, 2003). Generally, findings of SM and other atypical proliferations of bronchial mucosa in persons exposed to various noxae (air pollution, smokers, miners in asbestos mines, truck drivers, etc.) are very common (Couland and Kourilsky, 1953; Weller, 1953; Farber et al., 1954; Sanderud, 1956; Berkheiser, 1959, 1963, 1963, 1969; Saccomano et al., 1965, 1970; Lamb and Reid, 1968; Plamenac and Nikulin, 1969; Plamenac et al., 1972 a,b; Plamenac et al., 1973; Plamenac et al., 1979; Plamenac et al., 1980; Plamenac et al., 1981). Hyperplasia of goblet, mucus-producing cells established in $64.70 \%$ of the studied horses was reported by a series of authors (McPherson and Thompson, 1983; Schoon and Deegen, 1983; Winder and von Fellenberg, 1987; Winder and von Fellenberg, 1988; Kaup et al., 1990 a,b; Costa et al., 2001; Slocombe, 2001). In the lumen of bronchi and bronchioli of all studied horses accumulation of a large amount of thick viscous mucus that makes mucosal plugs which occasionally obstruct the lumen of these airways, was reported by many other authors, as well (McPherson and Thompson, 1983; Schoon and Deegen, 1983; Winder and von Fellenberg, 1987; Winder and von Fellenberg, 1988; Kaup et al., 1990 a,b; Costa et al., 2001; Robinson, 2001; Zinkl, 2002; Slocombe, 2003). Eosinophillic granulocytes are a characteristic finding in the sputa of asthmatic patients, together with findings of 
Curshman's spirals and Charcot-Layden's crystal (resulting from the degradation of eosinophillic granulocytes under the influence of their phospholipases). It is also well known that cytological diagnosis of this disease is complex and Creola bodies is the most important finding. Also, the presence of Curshman's spirals is not pathognomonic for asthma only as they may be found in other numerous pathological conditions. Also, eosinophils and Charcot-Layden's crystals have been noted in the sputa of patient with pneumonia, echynococcus, lung tuberculosis as well as in patients with lung carcinoma.

In impression preparations from the tracheal bifurcation in the studied material the predominant cellular population comprises desquamated columnar cells recorded in $98.04 \%$ studied horses, in agreement with other published reports (Beech, 1975; Hewson and Viel, 2002; Zinkl, 2002). Desquamation and lesions of the cylindrical epithelium with loss of ciliae from these cells was registered by Hewson and Viel (2002), as well. Beside bacteria and yeasts that were isolated from lung samples (Streptococcus equi, Streptococcus pyogenes, Staphylococcus aureus, Enterococcus sp., Enterobacter sp., Citrobacter sp., Klebsiella sp., Proteus mirabilis, Pseudomonas sp., Escherichia coli, Candida albicans) fungi Saccharopolyspora rectivirgula, Aspergilus fumigatus and Thermoactinomyces vulgaris have been suggested in literature as the most important factors in the occurrence of chronic obstructive pulmonary disease.

Finally, based on results of our study and literature data we may suggest that the pathogenesis of COPD in horses and lung emphysema is somewhat different from the same disease and asthma in humans in spite of numerous similarities. Namely, in humans the main role in the etiology is played by chronic bronchitis (etiology in horses is different), where the predominant provoking factor is smoking, but one may not overlook adverse environmental influences and air pollution (the same applies to horses). Also, in humans, a very important role is played by $\alpha 1$-antitrypsin deficiency (emphysema without bronchitis), which is not the case in horses. There is no asthma in horses (at least not pathomorphologically) while in humans it represents an important component of chronic obstructive pulmonary disease that in its pure form (non-smoker's asthma) it rarely results in emphysema. In horses, the disease most probably begins with recurrent bronchitis that spreads resulting and develops in more or less diffuse bronchiolitis, after which distension follows and subsequently destruction of alveolar spaces, i.e. COPD is accompanied with emphysema with all pertinent consequences.

\author{
Address for correspodence: \\ Mr Darko Marinković \\ Department of pathology \\ Faculty of veterinary medicine \\ Bulevar Oslobodjenja 18 \\ 11000 Belgrade \\ Republic of Serbia \\ E-mail: darko@vet.bg.ac.yu
}




\section{REFERENCES}

1. Beech J, 1975, Cytology of Tracheobronchial Aspirates in Horses, Vet Pathol 12, 157-64.

2. Berkheiser SW, 1959, Bronchial proliferation and metaplasia associated with bronchiectasis, pulmonary infarcts and anthracosis, Cancer, 12, 499-508.

3. Berkheiser SW, 1963, Bronchial proliferation and metaplasia associated with thromboembolism. A pathologic and experimental study, Cancer, 16, 205-11.

4. Berkheiser SW, 1963, Epithelial proliferation of the lung associated with cortisone administration. A pathologic and experimental study, Cancer, 16, 1354-64.

5. Berkheiser SW, 1969, Bronchiolar epithelial changes associated with congenital heart diseases. Amer Rev Res Dis, 100, 735-7.

6. Bracher V, von Fellenberg R, Winder CN, Gruening G, Hermann M, Kraehenmann A, 1991, An investigation of the incidence of chronic obstructive pulmonary disease (COPD) in random populations of Swiss horses, Equine Vet J, 23, 136-41.

7. Costa LRR, Seahorn TL, Moore RM, Oliver JL, Hosgood GL, 2001, Plasma and bronchoalveolar fluid concetrations of nitric oxide synthesis in the lungs of horses with summer pastureassociated obstructive pulmonary disease, Am J Vet Res, 62, 1381-6.

8. Couland E, Kourilsky R, 1953, Modification des epithelium et des parois bronchiques produties chez le cobaye par inhalation des vapeurs parafine, Rev Tuberc (Paris), 17, 1153-64.

9. Đuričić S, Zlatković M, Babić D, Gligorijević D, Plamenac $P, 2001$, Sputum Cytopathological Findings in Pig Farmers, Pathol Res Pract, 197, 145-55.

10. Farber SM, Rharr SL, Traunt HF, Wood DA, Gorman RD, 1954, Metaplasia and dysceratosis of bronchial epithelial cells following inhalation of trypsin and desoxyribonuclease, Lab Invet, 3 , 333-8.

11. Geisel O, von Sandersleben J, 1987, Pathomorphology of chronic obstructive lung disease in the horse, Tierarztl Prax Suppl, 2, 52-6.

12. Hewson J, Viel L, 2002, Sampling, Microbiology and Cytology of the Respiratory Tract, In: Lekeux $P$ : Equine Respiratory Diseases (ed). International Veterinary Information Service, Ithaca, New York, USA.

13. Kaup FJ, Drommer W, Deegen E, 1990 a, Ultrastructural findings in horses with chronic obstructive pulmonary disease (COPD) I: Alterations of the larger conducting airways, Equine Vet J, 22, 343-8.

14. Kaup FJ, Drommer W, Deegen E, 1990 b, Ultrastructural findings in horses with chronic obstructive pulmonary disease (COPD) II: Pathomorphological changes of the terminal airways and the alveolar region, Equine Vet $J$, 22, 349-55.

15. Lamb D, Reid L, 1968, Mitotic rates, goblet cell increase and histochemical changes in mucus in rat bronchial epithelium during exposure to sulphur dioxide. J Path Bact, 96, 97-111.

16. Lopez A, 2001, Respiratory System, Thoracic cavity, and Pleura, In: McGavin MD, Carlton WW, Zachary JF: Thomson's Special Veterinary Pathology, III Ed, Mosby A Hartcourt Health Sciences Company, St. Louis.

17. McPherson EA, Lawson GHK, Murphy JR, Nichols. on JM, Fraser JA, Breeze RG et al, 1978, Chronic obstructive Pulmonary Disease (COPD): Identification of Affected Horses, Equine Vet J, 10, 4753.

18. McPherson EA, Lawson GHK, 1974, Some Aspects of Chronic Pulmonary Diseases of Horses and Methods used in their Investigation, Equine Vet $J, 6,1-6$.

19. McPherson EA, Thompson JR, 1983, Chronic obstructive pulmonary disease in the horse I. Nature of disease, Equine Vet J, 15, 203-6.

20. Moore JE, Matsuda M, Yamamoto S, Buckley T, 2004, Hypersensitivity Pneumonitis in the Horse: An undiagnosed Condition?, Journal of Equine Veterinary Science 24, 510-1.

21. Naylor B, Railey C, 1964, A pitfall in the cytodiagnostics of sputum of asthmatics, J Clin Pathol, 17, 84-9.

22. Naylor $B, 1962$, The shedding of the mucosa of the bronhial tree in asthma, Thorax, 17, 69-72. 
23. Plamenac P, Nikulin A, Pikula B, Marković Z, 1972 a, Cytology of the respiratory tract in asbestos miners, Acta Med lug, 32, 297-309.

24. Plamenac P, Nikulin A, Pikula B, Gmaz-Nikulin E, Zeljo A, 1981, Cytological changes of the respiratory tract in children as consequence of high levels of air pollution exposure, Folia Med Univ Sar, 16, 41-50.

25. Plamenac P, Nikulin A, Pikula B, Vujanić G, 1979, Cytologic changes of the respiratory tract as a consequence of air pollution and smoking, Acta Cytol, 23, 449-53.

26. Plamenac $P$, Nikulin A, Pikula B, 1972 b, Cytology of the respiratory tract in former smokers, Acta Cytol, 16, 256-300.

27. Plamenac $P$, Nikulin A, Pikula $B, 1974$, Cytologic changes of the respiratory epithelium in iron foundry workers, Acta Cytol, 18, 34-40.

28. Plamenac $P$, Nikulin A, 1969, Atypia of the bronchial epithelium in wind instrument players and singers, Acta Cytol, 13, 274-8.

29. Plamenac $P$, Nikulin A, Pikula B, 1973, Cytological changes of the respiratory tract in young adults as a consequence of high levels of air pollution exposure, Acta Cytol, 17, 241-4.

30. Plamenac P, Nikulin A, Pikula B, Gmaz-Nikulin E, Kafeđić A, 1980, The influence of air pollution and smoking on cytologic changes of the respiratory epithelium of professional truck drivers, Folia Med Univ Sar, 15, 49-61.

31. Robinson NE, 2001, Recurrent Airway Obstruction (Heaves). In: Lekeux P: Equine Respiratory Diseases (ed), International Veterinary Information Service, Ithaca, New York, USA.

32. Robinson NE, 2001, Smooth muscle and bronchodilatators, - International Workshop on Equine Chronic Airway Disease, Michigan State University 16-18 June 2000, Equine Vet J, 33, 5-19.

33. Saccomano G, Saunders RP, Archer VE, Auerbach O, Kuschner M, Beckler PA, 1963, Cytology of the lung: the cytology of sputum prior to the development of carcinoma, Acta Cytol, 9, 413-23.

34. Saccomano G, Saunders RP, Klein MG, Archer VE, Brennan L, 1970, Cytology of the lung in reference to irritant, individual sensitivity and healing, Acta Cytol, 14, 377-81.

35. Sanderud K, 1956, Squamous epithelial metaplasia in the respiratory tract in uremics, Brit J Cancer, 10, 226-31.

36. Schoon H-A, Deegen E, 1983, Histopathologie der chronisch obstruktiven Bronchitis bei klinisch manifest erkrankten Pferden, Tierarztl Prax, 11, 213-21.

37. Slocombe R, 2001, Pathology of the airways - International Workshop on Equine Chronic Airway Disease, Michigan State University 16-18 June 2000, Equine Vet J, 33, 5-19.

38. Slocombe RF, 2003, Diagnosis of Equine Respiratory Disease: Postmortem Methods and Lesion Interpretation. In: Lekeux $P$, Equine Respiratory Diseases (ed). International Veterinary Information Service, Ithaca, New York, USA.

39. Trailović $D R, 2000$, Hronično opstruktivno oboljenje pluća, u Trailović DR, Respiratorne bolesti konja, Fakultet veterinarske medicine, Univerzitet u Beogradu.

40. Watson JL, Stott JL, Blanchard MT, Lavoie J-P, Wilson WD, Gershwin LJ et al, 1997, Phenotypic Characterization of Lymphocyte Subpopulations in Horses Affected with Chronic Obstructive Pulmonary Disease and in Normal Controls, Vet Pathol, 34, 108-16.

41. Weller TW, 1953, Metaplasia of bronchial epithelium, postmortem study, Amer J Path, 23, 768-74.

42. Winder NC, von Fellenberg R, 1987, Chronic small airway disease in horses slaughtered in Switzerland, Schweiz Arch Tierheilkd, 129, 585-93.

43. Winder NC, von Fellenberg R, 1988, Chronic airway disease in the horse: Immunohistochemical evaluation of lungs with mild, moderate and severe lesions, Vet Rec, 122, 181-3.

44. Zinkl JG, 2002, Lower Respiratory Tract. In: Cowel RL, Tyler RD: Diagnostic Cytology and Hematology of the Horse, II Ed, Mosby, St Louis. 
Acta Veterinaria (Beograd), Vol. 57, No. 2-3, 157-167, 2007.

\title{
MORFOLOŠKI NALAZ NA PLUĆIMA KONJA SA HRONIČNIM OPSTRUKTIVNIM OBOLJENJEM PLUĆA (COPD)
}

\author{
MARINKOVIĆ D, ALEKSIĆ-KOVAČEVIĆ SANJA i PLAMENAC P
}

\begin{abstract}
SADRŽAJ
U ovom radu su izneti rezultati ispitivanja zastupljenosti i karakteristika hroničnog opstruktivnog oboljenja pluća (COPD) na osnovu morfoloških i citoloških promena na plućima konja. Makroskopski su pregledana pluća od 51 konja različite starosti i pola i uzorkovano je tkivo pluća za patohistološka ispitivanja. Citološka ispitivanja su sprovedena na otisak preparatima sa bifurkacije dušnika. Patohistooški preparati su bojeni hematoksilinom i eozinom (HE), toluidin plavim (TB), Gimzom (Giemsa), PAS-om i Pearls-ovom reakcijom za detekciju gvožđa. Peroksidaza anti-peroksidaza metod (PAP) korišćen je za obležavanje CD3+ (T limfociti) i CD79 + (B limfociti). Citološki otisak preparati bifurkacije dušnika su bojeni hematoksilinom i eozinom (HE), Gimzom (Giemsa) i PAS-om.

Emfizem i izostanak kolapsa pluća čine najčešći makroskopski nalaz kod ispitivanih konja, dok je alveolarni emfizem, češće u formi distenzivnog emfizema $(54,90 \%)$, a ređe u formi destruktivnog emfizema (15,69\%) ustanovljen kod $70,59 \%$ ispitivanih konja. Patohistološki je kod svih ispitivanih konja uočen hronični bronhitis/bronhiolitis, sa karakterističnim promenama u lumenu, na sluznici, krznu i glatko-mišićnom sloju. Imunohistohemijski je u plućima uočeno povećanje imunoreaktivnosti. Najčešće uočena promena na citološkim otisak preparatima dušnika bila je gusta, viskozna, PAS pozitivna sluz koja formira Kuršmanove spirale. Dominantnu ćelijsku populaciju čine deskvamisane ćelije epitela vazdušnih puteva, kao i eozinofilni i neutrofilni granulociti, mastociti, eritrociti i alveolarne makrofage. Iz uzoraka pluća bakteriološki su izolovani kako primarni patogeni pluća, tako i potencijalni kontaminenti i uzročnici sekundarnih infekcija.

Svi navedeni nalazi su međusobno povezani i ukazuju na činjenicu da hronični bronhitis/bronhiolitis čini osnovni supstrat hroničnog opstruktivnog oboljenja pluća konja i da ima kombinovanu inflamatornu i imunološku etiologiju, a da je emfizem sekundarnog karaktera i javlja se kao posledica opstrukcije vazdušnih puteva.
\end{abstract}

